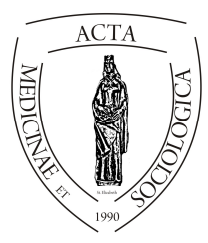

Acta Medicinae et

Sociologica (2020)

UNIVERSITY OF

DEBRECEN

Vol. 11. No. 30. (82-94)

FACULTY OF

HEALTH

doi:

NYÍREGYHÁZA

\title{
A szociális ellátórendszer sajátosságai Kárpátalján
}

\author{
Báthori-Tárczy Zita ${ }^{1}$, Popovich Anna ${ }^{2}$, Katsora Olexander ${ }^{3}$ \\ ${ }^{1}$ nyugalmazott egyetemi docens, Ungvári Nemzeti Egyetem, Társadalomtudományi Kar, Szociológia és Szociális \\ munka Tanszék. Universytets'ka St, 14Uzhhorod. \\ 2, egyetemi docens, Ungvári Nemzeti Egyetem, Társadalomtudományi Kar, Szociológia és Szociális munka Tan- \\ szék. Universytets'ka St, 14Uzhhorod. \\ ${ }^{3}$ tanár, Ungvári Nemzeti Egyetem, Társadalomtudományi Kar, Szociológia és Szociális munka Tanszék. \\ Universytets'ka St, 14Uzhhorod.
}

\section{INFO}

ABSTRACT

Abstract. The Characteristic Features of Social Care System in Transcarpathia. The study deals with the social protection system in Transcarpathia; presents the structure of Ukrainian social protection and describes its components; the current economic, social and social situation characterized in the light of past and present aspects; outlines the peculiarities and tasks of Ukrainian state and non-state social protection its tasks and the factors limiting their fulfilment; clarifies the concept of social protection, welfare and well-being in order to avoid misunderstanding and contradictions in their interpretation; presents the system of Transcarpathian social services through certain activities and good practices of some major state, non-state and church institutions, draws conclusions on the situation and development tendencies.

\footnotetext{
Kulcsszavak:

Kárpátalja, szociális védelem, szociális szolgáltatások, jólét, jól-lét, állami és nem állami szervezetek, intézménytelenítés, kettős intézményesítés
} 


\section{Bevezetés}

Kárpátalja szociális ellátórendszerének fejlődését nem lehet az ukrán nemzeti tendenciáktól és egy sor fontos előzménytől elválasztva vizsgálni. Az ellátórendszer kialakulását a paternalista szociális politika, a túlzott centralizáció és a szociális védelem területéről korábban teljesen hiányzó civil szektor megjelenése jelentősen befolyásolja. Napjainkban, az Ukrajna keleti régiójában folyó harci események, a romló gazdasági helyzet, a jelentős társadalmi feszültségek nagyban megnehezítik a szociálpolitika megvalósítását. A jövedelmek és az igények kielégítése szintjén óriási különbségek mutatkoznak, ami a lakosság polarizációjához vezet. A „hagyományos" társadalmi problémák (szegénység, munkanélküliség, hajléktalanság, gazdasági migráció, fogyatékosság, árvaság) súlyosbodnak és a társadalmi színtéren mellettük újak jelennek meg: ilyen a belső migráció, a keleti-ukrajnai harci események következtében bekövetkezett hirtelen elszegényedés és a rokkantság. A közigazgatási-területi reform, a fiskális decentralizáció, a helyi önkormányzatok szerepének erősödése, a szociális szolgáltatások deinstitucionalizációja, a nyugdíjreform, a célzott támogatás rendszerének bevezetése a lakosság leginkább veszélyeztetett rétegei számára stb. merőben új helyzetet teremt. A szociális szolgáltatásokat nyújtó civil szektor szerepe növekszik, a stabil társadalmi körülményekhez igazított, régi szociális ellátórendszert fokozatosan egy viszonylag új fogalom, a lakosság szociális védelme váltja fel.

A szociális védelem fogalmának az ukrajnai nemzeti jogszabályokban nincs hivatalos definíciója. Nincs egységes szociális kódex sem, amely a szociális védelem minden aspektusát szabályozná, annak ellenére, hogy az országban szemléletváltás történt. Korábban a szociális védelem fogalma a szociális ellátás fogalmával, azaz a pénzbeli juttatásokkal volt azonos, és kizárólag szociális kockázatok esetén került szóba. Mára már a szociális védelem tágabb értelembe vett jelentése elfogadott, és a társadalmi élet sok területét érinti: a szociális ellátórendszert, oktatást, egészségügyet, foglalkoztatást, társadalombiztosítást, a szociális szolgáltatásokat stb. Napjainkban a szociális védelem kontextusában gyakran kerül szóba a társadalmi jólét, jól-lét fogalma, a globalizáció és regionalizáció államra gyakorolt hatásának kérdései. A fent említett fogalmak tisztázását azért tartjuk fontosnak, mert igen nagy eltérések, sőt ellentmondások vannak azok értelmezésében.

A szociális szféra fejlődése, funkcionálása, tendenciáinak szempontjából meghatározó tényező az adott országban uralkodó politikai gondolkodás, hisz az uralkodó politikai álláspont határozza meg az állami és a civil szektor szerepkörét, ezek helyét, feladatait, lehetőségeit, felelősségvállalását, a nemzetközi szervezetekkel való együttmüködést és a szociális szféra területére érvényes összes tendenciát.

Jelen tanulmányban a szociális védelem széleskörü értelmezését fogjuk alkalmazni, jellemezzük összetevőit, így a szociális garanciák, a társadalombiztosítás, az állami szociális segélyek és a szociális szolgáltatások rendszerét. Főbb forrásként a nemzeti törvények, jogszabályok, tanulmányok, állami statisztikai felmérések eredményei és közigazgatási jelentések adatai szolgálnak. A tanulmány azon része, amely Ukrajna helyét próbálja behatárolni az államkoncepciók rendszerében, valamint a jólét és a jól-lét fogalmainak értelmezésével foglalkozik, a külhoni magyar 
kutatók számára 2019-re kiírt Domus pályázat keretében a Kodolányi János Egyetemen folytatott kutatásnak köszönhetően született.

\section{A jólét és jól-lét}

Ukrajna gazdaság- és szociálpolitikájában a rendszerváltás közel 30 éve alatt komoly paradigmaváltás történt, új nézőpontok születtek, új társadalmi mozgalmak fejlődtek, szociális gazdaság van kialakulóban. Mindez a rendkívül nehéz és változó gazdasági-, politikai- és kulturális viszonyok miatt nagyon lassan zajlik. Nemzetközi összehasonlítás szerint a világ közel negyven országa mellett Ukrajna a tekintélyelvü versenyző államok kategóriájába tartozik és formális demokratikus intézményrendszerrel rendelkezik (Hervainé 2015). A Szovjetunió széthullása azt eredményezte, hogy az ország fejlődésében erősen visszacsúszott, a 2014-től keleten folyó háború a fejlődést tovább lassítja, csökkentve ezzel a lakosság politikai, szociális, valamint gazdasági biztonságát. Ugyanúgy, mint a többi informális biztonsági rendszerrel rendelkező országban, az ukrán politikai gazdaságtanra is hatnak a kapitalista országok, a piacát multi- és transznacionális vállalatok, szervezetek erősen befolyásolják. A lakosság jelentős részét politikai és gazdasági értelembe vett kirekesztettség jellemzi. Segélyek és juttatások bonyolult rendszere müködik, mely nem fedezi még minimális mértékben sem a szükségleteket. A lakosság, hogy talpon tudjon maradni, számtalan megoldáshoz folyamodik. Jellemző a belföldön és külföldön végzett vendégmunka, az elvándorlás, az agyelszívás következtében tapasztalható értelmiségi réteg kivándorlása, lassú el- és átszivárgása jobb életkörülményeket és lehetőségeket biztosító országokba. Erős a gazdasági migráció, amely korábban a férfiak, utóbbi években főleg a nők nagy számát érinti. Ez a jelenség komoly következményekkel jár, és egy sor komoly, új, családi, szociálisés gazdasági problémát vet fel. Az illegális és féllegális üzlet virágzása, az aggasztó bünözési statisztika a hatalom részéről komoly lépéseket sürget. A politikusok országért és lakosságért való tenni akarása, cselekvőképessége a közvélemény által erősen megkérdőjelezett, az emberek bizalma, hite a változásokban erősen megrendült, a lakosság nagy száma a megélhetéséért küzd, a politikát szükséges rosszként éli meg. Külföldről finanszírozott grantok, NGO-k projektjei, egyházi működtetésű intézmények egészítik ki/helyettesítik a hiányos állami szociális intézményrendszereket. Az országban a hangsúly az alapvető, égető szükségletek kielégítésére van helyezve, sok, törvény által elöírt kedvezményben, juttatásban a lakosság csak azon része részesül, amely tud is annak létezéséről. Sokszor a törvény által előírt jogok sem teljesülnek. A jólét meghatározása kapcsán inkább a gazdasági és politikai biztonság, fenntarthatóság kérdése merül fel, de az országra a gazdasági fejlődés, a banki rendszer és a befektetések bizonytalansága a jellemző. A lassúság és bürokratizmus révén a szociálpolitika nem éri el a kellő hatását, így Ukrajna tekintetében továbbra is felemelkedő, demokratikus jóléti rezsim színében tetszelgő posztkommunista illfare rezsimről beszélhetünk. A törvény által elöírt, állami, megyei és regionális szintü szociális intézményrendszer ki van ugyan építve, de ezek főleg adminisztratív szolgáltatásokat nyújtanak, kis számú szakembergárdával mü- 
ködnek, akik gyakran a megfelelő szakirányú felkészítés hiányában a gyakorlatban nem tudnak effektív munkát kifejteni.

Ahhoz, hogy precízen meg tudjuk határozni a jólét és a jól-lét fogalmát statisztikusokra, környezettudománnyal, gazdaság- és társadalomtudománnyal, valamint szakpolitikával foglalkozó szakemberekre van szükség. De ahhoz hogy szétválaszszuk ezeket a fogalmakat elég, ha tudjuk, hogy a jólét meghatározásánál az egyén és társadalom szempontjából is központi szerephez az anyagiak jutnak, a jól-lét fogalma pedig az életminőségről szól, ami az egyén, csoportok, az egész társadalom széles értelembe vett életterét, érzelmi és tudati viszonyulásait érinti.

Magyarországon a jól-lét, a társadalmi haladás, a fenntartható fejlődés mérését a Nemzeti Fenntartható Fejlődési Stratégia 2013-as elfogadása tette lehetővé. Indikátorfejlesztései, a brit Statisztikai Hivatal tanulmányai alapján, a korábban nem mért jól-léti mutatókra is kitértek, így Magyarország viszonylatában beszélhetünk közösségi, munkahelyi, iskolai, családi és egyéni jól-létről, de vizsgálják a jól-lét kérdését az életciklus folyamatában is, így gyermekkori, ifjúsági, felnőttkori és időskori jóllétről is vannak adatok. A magyar fejlesztési közpolitikai programok kötődnek az EU-programokhoz és az egészség, az egészség szociális hátterének alakítását fejlesztő programokra, városok, megyék fejlesztési programjaira, részletes operatív fejlesztési tervek kialakítására teszik a hangsúlyt (Hervainé 2015).

Az ukrajnai kutatók zöme a jólét és a jól-lét kérdéseit nem választja szét. Csecsely O. M. az Államigazgatás a gazdasági szférában címü könyvében arról ír, hogy a jólét fogalma rendkívül sokrétü, szintje olyan tényező, amely gátolja vagy előmozdítja a fejlődést, tovább ösztönzi vagy korlátozza az egyének és a lakosság aktív gazdasági magatartását. A lakosság jólétét a termelés, árucsere, felosztás és fogyasztás terén tapasztalható társadalmi tevékenység feltételei határozzák meg. A jólét alakítja a szükségletek hierarchiáját és határozza meg a szükségletek kielégítésének szintjét is. Összetevői vizsgálatakor 3 fontos és szerkezetileg külön-külön is összetett területet kell vizsgálni - 1. a közjólétet, 2. a fejlődés minőségét valamint 3. az életszínvonalat és az életminőséget. A közjólét értékelése a GDP jövedelemeloszlás egyenlőtlenségeinek figyelembevételével kerül elemzésre. A fejlődés minőségének értékelése során a humán tőke fejlődéséhez szükséges javak biztosítását mérik. A lakosság életszínvonalát a lakosság jövedelme, a szociális biztonság, az egészségügyi ellátás, az oktatás, a demográfiai helyzet jellemzi. Az életminőség meghatározása ökológiai, gazdasági, szociális, politikai, demográfiai indikátorok mérése folytán történik (Csecsely 2015).

A lakosságnak égető szüksége van a segítségre. Ezt regionális szinten a Kárpátaljai Megyei Állami Adminisztrációhoz beérkezett lakossági kérelmek nagy száma is bizonyítja. A megyei vezetés a lakosság kérelmeivel kapcsolatos tevékenységéről szóló hivatalos jelentése szerint 2018 első felében 1882 kérelmet regisztrált, ezek 80,1\%-a a szociális védelem hatásköréhez tartozó kérdésben érkezett (Kárpátaljai Megyei Állami Adminisztráció 2019). A kérelmezők között 668 nyugdíjas, 658 fogyatékkal élő, a terrorellenes akció (ATO) 504 résztvevője, 56 munka veteránja, 39 nagycsaládos, 16 csernobili katasztrófa következményeinek felszámolásában résztvevő személy és 11 egyedülálló anya volt. A gondok enyhítésére, a lakosság védelmében, egyszeri segélyeket adnak „Turbota”, regionális fejlődést segítő állami program keretében. . 


\section{A lakosság szociális védelmi rendszerének szervezeti felépítése}

Ukrajna Alkotmánya szerint Ukrajna szociális állam. A szociális állam fogalma, pedig elöírja az objektív okok miatt magukat önállóan ellátni képtelen állampolgárok támogatását. A szociális védelmi rendszer - az állam gazdasági, jogi, szervezési és egyéb intézkedéseinek rendszere az állampolgárok szociális jogainak és garanciáinak biztosítása érdekében jött létre és mindenekelött az állam támogatását hivatott garantálni azoknak az állampolgároknak, akik erre a koruknál, egészségi állapotuknál, szociális helyzetüknél, elégtelen létfeltételeiknél fogva rá vannak szorulva. A lakosság szociális védelmét a központi végrehajtó szerv, Ukrajna Szociálpolitikai Minisztériuma biztosítja, amelyhez az Állami Munkaügyi Szolgálat, Ukrajna háborús veteránok és az antiterrorista hadmüveletben résztvevők ügyeivel foglalkozó Állami Szolgálat, Ukrajna Nyugdíjalapja és az Állami Foglalkoztatási Szolgálat tartozik. A járási és városi állami közigazgatás gyermekügy szolgálatai és a lakosság szociális védelmét ellátó osztályok a Megyei Állami Közigazgatási Hivatalok részei, a hozzájuk tartozó egységekkel együtt. Az állam szociálpolitikájának a megvalósításáért regionális szinten, így Kárpátalján is, a megyei állami adminisztráció Munkaügyi és Szociális Védelemi Főigazgatósága felel. A Főigazgatóság intézményrendszeréhez Kárpátalján 19 járási és városi munkaügyi és szociális védelemi valamint szociális szolgáltatások igazgatósága; 19 territoriális szociális szolgáltatóközpont; 1 fogyatékkal élők szakmai-módszertani és társadalmi rehabilitációjának területi központja; 7 bentlakásos intézmény tartozik (a munkácsi, nagyszőlősi, vilsáni (Égermező) gyermekeket, a nagyszőlősi időseket befogadó intézmény; a turjaremetei valamint a két munkácsi pszicho-neurológiai intézmény).

A Kárpátaljai Megyei Állami Adminisztráció Munkaügyi és Szociális Védelemi Főigazgatósághoz tartozik továbbá a Megyei Munkaközvetítő Iroda; a Megyei Állami Adminisztráció Gyermekvédelmi Szolgálata; Megyei Állami Családügyi, Gyermekés Ifjúsági Szociális Szolgáltatások Központja és több állami szociális alap. A megyei intézményekhez járási és városi központok, szociális szolgálatok és más intézmények és szervezetek tartoznak. Az országban öt állami szociális társadalombiztosítási alap müködik. Ezek a Nyugdíjalap; Munkaképesség ideiglenes elvesztése; Munkahelyi balesetek és foglalkozási megbetegedések; és Munkanélküliség esetére vonatkozó kötelező állami Társadalombiztosítási Alapok, valamint a Csernobili katasztrófa következményeinek felszámolását és a lakosság szociális védelmét szolgáló Társadalombiztosítási Alap. A szociális védelem feladata a helyi és az állami költségvetésekből finanszírozott egészségvédelmi, lakásépítési, munkanélküliséget megelőző és munkanélkülieket támogató szociális programok kidolgozása is.

Az önkormányzati és az államhatalom területi szervezeti reformja Ukrajnában négy éve zajlik. A területi alapon szerveződő közösségek egyesítése terén Kárpátalja Ukrajnában az utolsó helyet foglalja el. A megyében 2016 és 2017 során hat összevont területi közösséget hoztak létre, 5 további közösség várja az egyesítésröl szóló megyei vezetés határozatát. Ez a folyamat 2018-ban nem folytatódott, annak ellenére, hogy a regionális hatalom optimalizálása érdekében 53 közösség létrehozását prognosztizálták (jelenleg 337 helyi tanács müködik). 2019-ben a közösségek még 
önként egyesülhetnek, ezután az összevonásról központilag döntenek, ami azt jelenti, hogy a szociális védelem az említett szervezeti átalakulások folytán a jövőben egészen más képet fog mutatni. Az új önkormányzati reform a szociális szolgáltatások biztosítását alapszinten a helyi közösségek hatáskörébe helyezi. Ez a szociális szolgáltatások decentralizációját jelenti. A tervek szerint a jövőben a területi vagy megyei rangú városokban ,átlátszó office” jellegü szociális szolgáltató központok létesülnek. A járási szintü szociális szolgáltatások feladatkörét pedig átruházzák a területi alapon szerveződő közösségekre. A szociális szolgáltatások ügyintézése korszerűsödik és a területi alapon szerveződő közösségekben „,front office” és „,back office" alkalmazásával fog történni.

\section{A lakosság szociális védelmi rendszerének összetevői}

Szociális garanciák. Állami szociális garanciának tekinthető a törvény által meghatározott minimálbér, jövedelem, nyugdíj, a szociális segély és más típusú szociális juttatás nagysága. A szociális garancia célja az állam alapvető társadalmi norma szerinti létminimum színtjénél nem alacsonyabb életszínvonalat biztosítson. A létminimumot az adott évre, Ukrajna állami költségvetéséről szóló törvény által meghatározott módon, Ukrajna Legfelsőbb Tanácsa hagyja jóvá évente. Elöször a létminimumot 2000-ben határozták meg 270 UAH összegben (Ukrajna Pénzügyminisztériuma). 18 év alatt, közel hét emelést követően 2018. december 31-re ez az összeg 1853 UAH. Elmondhatjuk, hogy hosszú távon ez a növekedés rendkívül jelentéktelen, így a létminimum a lakosság jövedelmének alakulására nincs pozitív hatással. A törvény módot ad arra, hogy a helyi önkormányzat az állami költségvetés által az adott évre megállapított létminimumnál nem alacsonyabb szintű regionális létminimumot állapítson meg, ami az ottani életszínvonal értékelése, regionális szociális programok kidolgozása és végrehajtása, a önkormányzati forrásokból finanszírozott szociális segélyekre való jogosultság megállapítása szempontjából nagyon fontos. Az adott évre vonatkozó havi minimálbér nagyságát az állami költségvetésről szóló törvény határozza meg, amely 2019. január 1-től 4173 UAH (Ukrajna Pénzügyminisztériuma).

A Pénzügyminisztérium adatai szerint az átlagfizetés Ukrajnában 2018 novemberében elérte a 9161 UAH-t (Ukrajna Pénzügyminisztériuma), de Kárpátalján, úgy mint sok más régióban, az átlagbér ettől az összegtől jelentősen eltér.

\begin{tabular}{|c|c|c|c|}
\hline Időszak & $\begin{array}{c}\text { Átlagfizetés } \\
(\mathrm{UAH})\end{array}$ & $\begin{array}{c}\text { Eltérés a hivatalos ukrajnai átlagfizetéstől } \\
(\mathrm{UAH})\end{array}$ & $\begin{array}{c}\text { Eltérés } \\
(\%)\end{array}$ \\
\hline 2016 december & 5597 & -878 & -13.6 \\
\hline 2017 december & 8127 & -650 & -7.4 \\
\hline 2018 november & 8390 & -770 & -8.4 \\
\hline
\end{tabular}

2. táblázat. Átlagfizetés alakulása Kárpátalján a Pénzügyminisztérium adatai szerint (UAH-ban). 
A reálbérindex, ami a nominálbér vásárlóerejének változását mutatja Kárpátalján $93,0 \%$ volt.

Nyugdíjellátás. Ukrajnában az elfogadott jogszabályok szerint az ország nyugdíjrendszere három pillérü. Az első pillért a kötelező állami nyugdíjbiztosítás szolidáris rendszer képviseli; a második pillér a kötelező állami nyugdíjbiztosítás felhalmozó rendszere; a harmadik pedig az önkéntes részvételen alapuló nem állami nyugdíjalap (Ukrajna 01.01.2019-es szerkesztésü 1058-IV számú 09.07.2003 évi törvénye „A kötelező állami nyugdíjbiztosításról”). A második pillér bevezetése, a várakozások szerint, a gazdasági növekedést, a nyugdíjasok jobb ellátását fogja segíteni, valamint csökkenti a szolidáris rendszer hiányát.

A nyugdíjrendszer alapja jelenleg továbbra is a szolidáris rendszer. A szolidáris rendszerben az öregségi, rokkantsági és az eltartó elvesztése esetén kiszabható nyugdíjak kerülnek megállapításra. A felhalmozási rendszerből lesz fedezhető az élethosszig tartó nyugdíj és az egyszeri kifizetések. Ma az adott időpontra érvényes átlagos fizetéshez kötődő biztosítási járulékokat a munkáltatók fizetik. Így, a mai nyugdíjasok alacsony nyugdíjának egyik legfontosabb okát a kormány a korábbi időszakok igazságtalan bérfeltételeivel magyarázza.

Az Ukrajna Állami Statisztikai Szolgálatának, az Ukrajna Nyugdíjalapjának, az Ukrajna Nyugdíjalapjának Kárpátaljai Főigazgatóságának elemzése szerint 2011 től a nyugdíjasok száma mind az országban, mind Kárpátalján csökken (2. táblázat). Ennek demográfiai okai vannak. A nyugdíjkorhatárt elérő emberek száma évente csökken, fokozatosan növekszik a nyugdíj megállapításához szükséges szolgálati idő, erős külföldre irányuló migráció, magas a halálozási arány.

\begin{tabular}{|l|c|c|c|c|c|c|c|}
\hline & 1996 & 2001 & 2011 & 2016 & 2017 & 2018 & 2019 \\
\hline $\begin{array}{l}\text { Ukrajna } \\
\text { (millió fó) }\end{array}$ & 14,4 & 14,4 & 13,7 & 12,2 & 11,9 & 11,7 & 11,5 \\
\hline $\begin{array}{l}\text { Kárpátalja } \\
\text { (ezer fó) }\end{array}$ & 276,2 & 288,2 & 294,3 & 287,5 & 283,3 & 280,0 & 274,6 \\
\hline
\end{tabular}

2. táblázat. A civil és katonai nyugdíjasok számának alakulása Ukrajna Statisztikai Szolgálatának 2019. január 1-i adatai alapján

A Kárpátalján a demográfiai helyzet miatt egy munkavállalóra átlagosan 1,4 nyugdíjas jut, de ez az arány járásonként eltérő. Az Ungvári járás viszonylatában egy munkavállalóra 0,5 nyugdíjas jut, Volóci járásban - 2,3, Técsői járásban - 2,1 (Az idei és múlt évi nyugdíjakról). 2019 elejei adatok szerint az összes kárpátaljai nyugdíjas közül 47 ezer dolgozik. A nyugdíjak összege gyakran változik, nominálértékének növekedése ellenére vásárlóereje folyamatosan csökken. A Nyugdíjalap a nyugdíjkifizetések átlagos összegéről szóló 2019. január 1-i adatai szerint a létminimum alatt élő nyugdíjasok aránya Ukrajnában 20\% körül van. (Ukrajna Nyugdíjalapja) Ugyanerre az időszakra számított átlagnyugdíj összege Kárpátalján 2139,66 UAH, ami a nyugdíjak emelését sürgeti. 2019 márciusától a kormány éves nyugdíjindex bevezetését tervezi. 
A nyugdíjbiztosítás második pillérének, a felhalmozási rendszernek a bevezetését 2019. január 1-jéről 2020-ra halasztotta. Ami a harmadik pillért illeti, a Pénzügyi Intézmények Állami Nyilvántartása 2018. június 30-ára Ukrajna 8 régiójában 62 nem állami nyugdíjalapot jegyez (Kijevben 44-et, ami az összes magánnyugdíjalap $71,0 \%$-a, kárpátaljai nincs közöttük). (A nem állami nyugdíjellátó rendszer fejlődésének eredményei)

Ukrajna Nyugdíjalapja fokozatosan fejleszti szolgáltatásait, köztük a távszolgáltatást is. Internetes portálján keresztül elektronikus szolgáltatásokat nyújt, kapcsolattartó központot müködtet, alkalmazza a mobil kommunikációt, e-mailt. A régióban dolgoznak az „egyablakos rendszer” kialakításán, a területi osztályokon eddig 23 távmunkahely létesült, (3 közülük összevont területi közösségben).

Állami szociális segélyek. A jelenlegi ukrán állami szociális támogatási rendszer hátrányos helyzetben, szegénységben és kiszolgáltatottságban élő lakossági csoportokat támogat: gyermekes családokat, a szegény családokat, nyugdíjra nem jogosult személyeket, fogyatékkal élő felnőtteket és gyermekeket, stb. 2019 január 8-i hivatalos statisztikai adatok szerint Ukrajnában 1512367 lakhelyéről elüzött és áttelepített személy él. Számukra a kormány speciális célzott támogatási programot létesített.

Állami szociális segélyeket Ukrajna Szociálpolitikai Minisztériumának alárendelt szociális védelemi rendszer irányító szervei nyújtanak. A csoportok szerinti és célirányos segélyek finanszírozása a központi költségvetésből történik a helyi költségvetésbe irányított szubvenciók átutalása révén. Célirányos támogatási elv alapján az alacsony jövedelmü családok családi segélyt kapnak valamint támogatást tüzelőre és kommunális szolgáltatások költségeire. A segélyek másik része csoportok szerinti vagy kombinált, és függ a jövedelemtöl.

Kárpátalján számos 2018 tíz hónapja alatt 87672 család kapott különböző típusú szociális segélyt: 60020 gyermekes család; 15819 gyermekkori fogyatékossággal élő személy és fogyatékkal élő gyermek; 10085 alacsony jövedelmü család (46\%-uk sokgyermekes család); 368 gyermek, akiért a szülők nem fizetnek gyerektartást. (Kárpátaljai Megyei Állami Adminisztráció Szociális Védelmi Főosztálya).

Szociális szolgáltatások. A lakosság szociális védelmének egyik legfontosabb öszszetevője a 2007 óta reformálás alatt álló szociális szolgáltatások rendszere. A fokozott figyelmet a népesség elöregedése, a fogyatékkal élök számának növekedése és egyéb társadalmi problémák megjelenése indokolja. Hivatalos adatok azt mutatják, hogy Ukrajnában minden évben több mint 1 millió nehéz körülmények között élő személy kerül nyilvántartásba. 2017-ben közülük 1347447 személy vett igénybe szociális szolgáltatást. Ugyanebben az időszakban Kárpátalján 19450 személy került nyilvántartásba és vett igénybe szociális szolgáltatást. (Ukrajna Statisztikai Szolgálata. Adatgyüjtemény)

„Ukrajna szociális szolgáltatásokról” szóló törvényének 12. cikke alapján az állami és nem kormányzati szociális szolgáltatások biztosítása valamennyi tulajdonforma felhasználásával és fejlesztésével történik (Ukrajna 07.01.2018-es szerkesztésü 966-IV számú 19.06.2003 évi törvénye „A szociális szolgáltatásról”). Az állami szektort állami tulajdonú, központi végrehajtó hatóságok által irányított szervezetek képviselik, a kommunális szektort, a helyi önkormányzati szerveknek alárendelt 
közösségi tulajdonú intézmények. A nem kormányzati szektorhoz szociális, jótékonysági, vallási szervezetek és szociális szolgáltatások nyújtásával foglalkozó magánszemélyek tartoznak. Kárpátalján zömében állami és kommunális intézmények müködnek, de fejlödik a magánszektor is.

A lakosság számára nyújtott szociális szolgáltatások elsősorban két szociális intézményrendszer hatáskörébe tartoznak, a család-, gyermek- és ifjúsági szociális szolgáltató központokhoz, valamint a lakosság szociális védelmét ellátó főosztályok hatáskörébe. Számos rájuk ruházott feladatkörben jelentős az átfedés, ami sürgeti az átszervezést és az emberi, anyagi, pénzügyi és technikai erőforrásokkal kapcsolatos problémák megoldását.

Nemzeti és regionális szinten bizonyos csoportok számára a szociális szolgáltatások intézménytelenítésének folyamata zajlik. Kárpátalján ez a folyamat az árvák és a szülői felügyelettől megfosztott gyermekek bentlakásos intézményei tekintetében a legeredményesebb. Az intézményi felügyelet családban vagy családi környezetben történő gondozásra és nevelésre módosul. 2017 végére 2216 volt az árvák és a szülői felügyelet nélkül maradt gyermekek száma. A túlnyomó többségük mára már családban van: 87 gyermeket örökbe fogadtak; 1485 gyámság alá van helyezve; 45 családi típusú gyermekotthonban 274 gyermeket helyeztek el, 124 nevelőszülőknél él. 117 gyermek továbbra is állami bentlakásos intézményben nevelkedik, közülük 62 az Oktatási és Tudományügyi Minisztériumhoz, 55 pedig a Szociálpolitikai Minisztériumhoz tartozó intézményben. (Ukrajna Statisztikai Szolgálata)

Az idősek bentlakásos intézményrendszerének alternatívájává a Kárpátalján 19 intézményből álló területi szociális szolgáltató központok hálózata vált, melyek szolgáltatásai iránt nagy az érdeklődés. A területi szociális szolgáltató központok az alapvető szociális szolgáltatások mellett otthoni ellátást, átmeneti elhelyezést, nappali intézményben történő ellátást, környezethez való adaptációt, természetbeni ellátást és egészségügyi segítségnyújtást biztosítanak. A listán innovatív szolgáltatások is megjelentek, így például a „Harmadik kor egyeteme", de van otthoni palliatív ellátás, bevásárlással és szállítással kapcsolatos szolgáltatás is. Kárpátalján a vallási közösségeknek és nemzetközi alapítványoknak köszönhetően az idősek általános szociális szolgáltató központjainak száma nő, 5 új típusú, kevés férőhelyes lakóotthon létesült. A pszichoneurológiai bentlakásos intézmények átszervezése folyamatban van, itt innovatív ellátási formák bevezetése folyik. Fontos megjegyeznünk, hogy elkezdődött, a szociális szolgáltatások szabványosítási folyamata is. Mára már húsznál több elfogadott szabvány határozza meg a szociális szolgáltatások tartalmát, intézményi feltételeit, az ehhez szükséges dokumentumok listáját, az ellátási eljárást, az ellátás időszabályozását és a minőségére vonatkozó követelményeket.

\section{Nem kormányzati szervezetek a szociális védelem rendszerében}

A civil társadalom fejlődése, a demokratikus normák meggyökerezése az országban, a közösség államalakításba való bevonását közvetlenül biztosító civil szervezetek jelenléte nélkül elképzelhetetlen. Ezek a szervezetek közvetítöként müködnek az 
állam és különböző társadalmi csoportok között, a civil társadalom részéről ellenőrzést gyakorolnak az állam tevékenysége felett, megakadályozzák az állam politikai, gazdasági és a társadalmi élet szféráinak monopolizálását, védik az állampolgárok jogait és érdekeit (Buko 2006).

A rendszerváltásként megélt 90-es éveket követően Ukrajnában gyökeresen megváltozott a szabadság, biztonság, jólét, jól-lét, jóléti társadalom értelmezése. Szovjetunió tagállamaként Ukrajnában is a szovjet adminisztratív rendszer erősen bürokratikus és autokrata ideológiai irányítása volt jellemző. A szociális kérdésekkel való foglalkozás kizárólagosan az állami feladat- és hatáskörhöz tartozott, ami a történelem során precedens nélküli módon, a magánszektor, szponzori segítség, mecenatúra és nemzetközi együttmüködés kizárásával zajlott. A 80-as évek végén felszínre kerülö, komoly társadalmi problémák kezelése, amit akkor már a nyíltan folytatott kutatások is kimutattak, erősen meghaladta az állam lehetőségeit. Ezek orvoslása céljából a 90-es évektől bizonyos területeken, szigorúan szabályozott és ellenőrzött módon, a politika teret engedett a civil szerveződéseknek, kezdeményezéseknek és viszonylag nyitottá vált a Nyugattal való diplomáciai, gazdasági, technológiai és információs együttmüködés iránt. A harmadik szektor Ukrajnában is fejlődésnek indult, mára a társadalmi felelősségvállalása jelentős. Az ukrán adótörvénykönyv 157. cikke a nonprofit szervezetek 12 csoportját különbözteti meg. Tevékenységük szabályozásában az ukrán törvényhozás liberálisnak számít. Hivatalos 2018 elejei statisztikai adatok szerint Kárpátalján 1589 nem kormányzati szervezet müködik (Ukrajna Statisztikai Szolgálata). Természetesen közülük nem mind nyújt szociális szolgáltatásokat. Ezen a területen a jótékonysági alapítványok a legaktívabbak, legtöbbjük szegények, betegek, fogyatékkal élők, idősek és a lakosság egyéb hátrányos helyzetben élő csoportok megsegítésével foglalkozik.

A Munkácsi görög katolikus egyházmegye „Kapiтac-Caritas” jótékonysági alapítványa közel 20 éve nyújt szociális szolgáltatásokat nehéz helyzetben élő emberek számára. Kiválóan müködik az „Otthoni Gondoskodás” (ukránul Domashnya-opika) projektjük, amely idős embereknek biztosít otthoni ápolást, szervez szabadidős tevékenységeket és háztartásvezetésben nyújt segítséget. Az Irgalom Háza nevet viselő intézményük átmeneti menedéket biztosít javarészt idős emberek számára, akik különböző okok miatt nem élnek családban. Az Alapítvány „Segítségnyújtás az antiterrorista hadmüvelet által érintett családoknak" nevü projektje is példaértékü. A projekt a kelet-ukrajnai harcok áldozatainak, valamint a lakóhelyüket elhagyni kényszerült embereknek, az elhunyt katonák és önkéntesek családjainak segít.

Számos más társadalmi és jótékonysági szervezet nyújt szociális szolgáltatásokat Kárpátalján. Így a jótékonysági szervezetek közül az ungvári „Élet útja” Szociális Rehabilitációs Gyógyközpont a fogyatékkal élő gyermekek és fiatalok komplex rehabilitációjával, a fogyatékkal élő gyermekek, fiatalok és családjaik jog- és érdekvédelmével foglalkozik. 2006-tól a Gyógyközpont koordinálja az ország összes korai intervenciós részlegének tevékenységét.

A „Választás” nevet viselő jótékonysági szervezet, a Kárpátaljai Szociális-, Munka-rehabilitációs és Szakmai Orientációs Regionális Központ missziója a megye fogyatékossággal élő fiataljainak közhasznú munkába való bevonása, amelyet az igények felmérése mellett a szakmai képzés és a foglalkoztatás elősegítése révén végzi. 
A Dorcas Kárpátalja Jótékonysági Alapítvány elősegíti az árvák, szülői felügyelettől megfosztott gyermekek és nemzeti kisebbségek szociális védelmét. Ugyanezek a csoportok, valamint a fogyatékkal élő gyermekek és fiatalok vannak a fókuszában Kárpátalja közigazgatási központja, Ungvár és az USA Oregon állambeli Corvallis között fennálló testvérvárosi program keretében 2001-től müködő amerikai-ukrán TOUCH Projectnek is.

A „Kárpátaljai Egészségügyi és Segítségnyújtási Bizottság” megyei jótékonysági szervezet speciális szükségletü, HIV/TBC fertőzött személyeket és romákat segít, illegális bevándorlók, menekültek és menedékkérők jogainak védelmét vállalta fel. 2009-ben erőfeszítéseiknek köszönhetően jött létre az enyhe és középsúlyos értelmi fogyatékkal élő fiatalok számára az első alternatív típusú intézmény, a „Paraszolka”.

Az „Opika” Jótékonysági Alapítvány célcsoportja a Perecsenyi bentlakásos iskola diákjai, végzősei, kárpátaljai árvák és félárvák. A szervezet hajléktalan gyerekekkel is foglalkozik. Jó példa még az idősek ellátását végző zsidó közösség jótékonysági alapítványa, a Hesed Shpira tevékenysége.

Az aktív munkájuk ellenére a nem kormányzati szervezetek többségének állami pénzügyi támogatása nem kielégítő. Ezt az elemzők a pénzügyi források korlátozottságával és a közpénzekből pályázatok útján elnyerhető támogatások átláthatatlanságával magyarázzák. Az állami finanszírozás, többek között az állami szociális megrendelés, az önkormányzat által kiírt pályázatok, a helyi közösségi alapok müködési mechanizmusai még nem müködnek megfelelően, így a nem kormányzati szervezetek pénzügyileg függnek a külföldi adományozó szervezetektől.

\section{Következtetések}

Összefoglalva elmondhatjuk, hogy Ukrajnában az instabil társadalmi-politikai és az ország keleti részén kialakult katonai helyzet jelentősen akadályozza a lakosság szociális védelmével kapcsolatos feladatok ellátását, a régiók és az egész ország fejlődését. A társadalmi kockázatok nem megfelelően prognosztizáltak, így azokat a szociális szféra nem képes teljeskörüen figyelembe venni. A kárpátaljai lakosság szociális védelme jelenlegi rendszerének elemzése több fontos megállapítást enged tenni. Először is, az országban a kettős intézményesítés jelenségével állunk szemben. A szociális védelem hagyományos modellje mellett, amely különböző típusú szociális segélyekre és juttatásokra, a szolidáris nyugdíjrendszerre, a bentlakásos intézmények müködtetésére stb. fekteti a hangsúlyt, párhuzamosan létezik egy merőben új is, amelynek fókuszában a célzott szociális segítségnyújtás, az intézménytelenítés és új típusú szociális szolgáltatások kialakítása áll. Mindez a meglévő regionális szociális védelem rendszerét a meglévő erőforrások korlátozottsága mellett a célorientáltság tekintetében fragmentálttá és improduktívvá teszi.

Másodszor, a lakosság szociális védelmének minden összetevője (szociális garanciák, társadalombiztosítás, állami szociális segélyezés, szociális szolgáltatások rendszere) ebben az időszakban reformok alatt áll, ami pozitív változásokat is eredményez. A nyugdíjreform, a bizonyos típusú segélyek monetizálása stb. befo- 
lyásolja a jövedelmek és a lakosság jólétének növekedését, ugyanakkor reálisan javuló tendenciája csak az intézménytelenítésnek van. A negatív irányba mutató és mellékes trendek megítélése továbbra is ellentmondásos.

Harmadszor, a jelenleg zajló közigazgatási reform kapcsán a lakosság szociális védelmének feladatkörei fokozatosan az egyesült területi közösségek hatáskörébe kerülnek. Emiatt ezen a területen a közösség felelösségvállalásának problémájával szembesülünk. Jól szervezett helyi szociális védelemi rendszer létrehozására van szükség, amely mobilabb lesz a nemzeti rendszernél. Ez esélyt adhat a szociális védelem minden egyes összetevőjének fejlesztésére és a kiszolgáltatott csoportok támogatásának javítására.

A jótékonysági szervezetek tevékenységének eredményessége kedvező feltételeket teremt a hatóságok és a lakosság közötti rendszeres párbeszédhez és erősíti a társadalmi stabilitást. A szociális szolgáltatások területén jól müködő jótékonysági intézmények száma növekszik, amelyek aktív részvételükkel pótolni igyekeznek a városi és járási szolgálatai figyelmét elkerülő problémák megoldását. Az ukrajnai jótékonysági tevékenységek szférájának elemzése arra enged következtetni, hogy az állam és a civil szervezetek szociálpolitikai iránya azonos, de a reformok komoly szociális tartalommal való feltöltést igényelnek. A körülmények sürgetik az állam, a gazdasági szereplők, a nem kormányzati szervezetek és a társadalom együttműködését a társadalmi problémák megoldása érdekében. Elmondható, hogy a lakosság védelmének sajátosságai, az állami és nem kormányzati szervezetek e területen végzett tevékenysége tágabb kontextusba helyezett, speciális kutatást indokol.

\section{Irodalomjegyzék}

1. A civil szervezetek 2017 évi tevékenysége Ukrajnában / Ukrajna Statisztikai Szolgálata. Adatgyüjtemény. 2018

2. A nem állami nyugdíjellátó rendszer fejlödésének eredményei 30.06.2018 évre https://www.nfp.gov.ua/files/OgliadRinkiv/NPF/OsnPokazn/NPF_II_kv_2018. pdf

3. A Kárpátaljai Megyei Állami Adminisztráció lakosság kérelmeivel kapcsolatos hivatalos jelentése / Kárpátaljai Megyei Állami Adminisztráció https://carpathia.gov.ua/storinka/zvit-shchodo-roboty-iz-zvernennyamygromadyan

4. A társadalom speciális figyelmét igénylő gyermekek védelme: Ukrajna Statisztikai Szolgálata. Adatgyüjtemény. http://www.ukrstat.gov.ua/ druk/ publicat/ kat_u/2018/zb/07/zb_zdpus_2017.pdf

5. Adatok az átlagnyugdíj nagyságáról /Ukrajna Nyugdíjalapja https://www.pfu.gov.ua/ category/ informatsiya/ byudzhet/ analityka/ dani-proserednij-rozmir-pensijnoyi-vyplaty/

6. Az idei és múlt évi nyugdíjakról ... https://www.pfu.gov.ua/zk/49860-propensiyi-roku-mynulogo-i-roku-novogo-rozpovidaye-kerivnyk-zakarpatskyhpensijnykiv-anastasiya-pentek/ 
7. Állami segélyek kiszabása és kifizetése 01.11.2018 évre / Kárpátaljai Megyei Állami Adminisztráció Szociális védelmi Főosztálya http://www.zaksoc. gov.ua/ index.php/ component/ content/ article /577--01112018

8. Átlagfizetés / Ukrajna Pénzügyminisztériuma https://index.minfin. com.ua /ua/labour/ salary/average/

9. Buko S.L. Специфіка активності міжнародних НУО на ринку соціальних послуг. (magyarul - A nem kormányzati szervezetek tevékenységének sajátosságai a szociális szolgáltatások terén) Multiverzum. Filozófiai Almanach. Kijev. 2006. № 54 .

10. Csecsely O. M. Állami igazgatás a gazdasági szférában. Vinnyica.Nilan. 2015 371 old. https:/pidruchniki.com/ 79750/ekonomika/ derzhavne_upravlinnya v ekonomichniy sferi

11. Hērvainé Szabó Gyöngyvér. Állami versenyképesség és jóléti modellek, társadalmi jól-lét és politikai ideológiák dinamikájában. A 21. Század eleji államiság kérdőjelei. Székesfehérvár. KJE.- 2015-13-48.

12. Hervainé Szabó Gyöngyvér. Kovács László, Schuchmann Júlia. KJF.2015A globális jól-léti közpolitikai áramlat fogadtatása, és hatása az OECD tagországokra. KJE.- 2015.

13. Létminimum Ukrajnában /Ukrajna Pénzügyminisztériuma. https://index. minfin.com.ua / ua/labour/ wagemin/

14. Minimális munkabér/ Ukrajna Pénzügyminisztériuma https://index. minfin.com.ua/ ua/labour/ salary/ min/

15. Reálbérindex / Ukrajna Pénzügyminisztériuma https://index.minfin.com.ua/ ua/labour/salary/index/

16. Ukrajna 01.01.2019-es szerkesztésü 1058-IV számú 09.07.2003 évi törvénye "A kötelező állami nyugdíjbiztosításról https://zakon.rada.gov.ua/ laws/show/ 1058-15

17. Ukrajna 07.01.2018-es szerkesztésü 966-IV számú 19.06.2003 évi törvénye „A szociális szolgáltatásról" https://zakon.rada.gov.ua/ laws/card/966-15

18. Ukrajna lakosságának szociális védelme: /Ukrajna Statisztikai Szolgálata. Adatgyüjtemény.

http://www.ukrstat.gov.ua/druk/publicat/kat_u/2018/zb/07/zb_szn_2017.pdf 